\section{Hanyang Medica I Reviews}

Hanyang Med Rev 2013;33:33-38

http://dx.doi.org/10.7599/hmr.2013.33.1.33

pISSN 1738-429X eISSN 2234-4446

\section{후생학적 전사조절 인자인 Polycomb 단백질들이 $\mathrm{T}$ 림프구 분화 및 활성에 미치는 영향}

전태훈

고려대학교 생명과학대학 생명공학부

\title{
Influence of Polycomb Proteins and Epigenetic Transcriptional Modifiers on the Development and Activation of T Lymphocytes
}

\author{
Taehoon Chun \\ Division of Biotechnology, College of Life Sciences and Biotechnology, Korea University, Seoul, Korea
}

Transcriptional regulation of a gene is not always correlated with genetic information inherited from parents because the transcription of specific genes is often governed by the modification of chromatin structure. The study of transcriptional regulation by modifying chromatin structure is well-known as "epigenetics". Several methods involved in the modification of chromatin structure have been developed in the mammalian species during evolution. Among those methods, methylations of specific DNA region or histone are often used to control specific gene transcription. Therefore, understanding the activity of proteins involved in DNA or histone methylation is an initial step to control the transcriptional activity of a specific gene. Polycomb group (PcG) proteins were known to be repressors of transcription of a specific gene by creating and maintaining methylation or ubiquitination of the specific region of histone. Dependent on the target histone, the activity of PcG proteins effects on the development of specific lineage cells or the activity of specific cell types. In this review, the function, expression and activity of PcG proteins related with the development or activation of T cells are discussed.

Key Words: Chromatin; Epigenomics; Histone Code; Polycomb-Group Proteins; T-Lymphocytes

\author{
Correspondence to: Taehoon Chun \\ 우136-713, 서울시 성북구 안암로 145 , \\ 고려대학교 자연계 캠퍼스 생명과학관 \\ 서관 317호 \\ Division of Biotechnology, College of Life \\ Sciences and Biotechnology, Korea \\ University, 317 Room, West Life Science \\ Building, Science Campus, Korea \\ University, 145 Anam-ro, Seongbuk-gu, \\ Seoul 136-713, Korea \\ Tel: +82-2-3290-3069 \\ Fax: +82-2-3290-3507 \\ E-mail: tchun@korea.ac.kr
}

Received 15 November 2012 Revised 3 January 2013 Accepted 10 January 2013

This is an Open Access article distributed under the terms of the Creative Commons Attribution Non-Commercial License (http://creativecommons.org/licenses/by-nc/3.0) which permits unrestricted non-commercial use, distribution, and reproduction in any medium, provided the original work is properly cited.

\section{서 론}

후생학적 유전(epigenetics)이란 크로마틴(chromatin)의 구조에 따라 특정 유전자의 전사(transcription) 개시가 달라진다는 뜻으 로, 동일한 유전자형을 가지고 태어난 일란성 쌍둥이에서도 환경에 따라 다르게 나타나는 표현형을 해석하기 위한 일환으로 연구되었 다. 크로마틴의 구조는 유전정보인 DNA와 유전정보와 결합하는 단백질 간의 상호작용 변화에 따라 달라지며, 이러한 변화는 특정 유전자의 전사뿐만 아니라, 핵 분열(mitosis), 유전자 복제(DNA replication) 등을 결정하는데 매우 중요한 요인으로 작용한다[1]. 따라서 크로마틴의 구조를 변화시키는 여러 가지 단백질들이 발견
되었으며, 그러한 단백질의 활성 연구도 많이 진행되어 있다. 폴리 콤 그룹(polycomb group, $\mathrm{PcG}$ ) 단백질들은 크로마틴 구조를 이루 고 있는 특정 히스톤(histone) 부분에 메틸기(methylation)나 유비 퀴틴(ubiquitin)을 붙여서 히스톤의 구조를 변화시키는 단백질들 로 알려져 있으며, 이러한 결과로 특정 유전자의 전사가 개시되지 않기 때문에, 전사저해인자로 알려져 있다[2,3]. 따라서, 폴리콤 그 룹 단백질들의 활성에 따라 특정 DNA와 결합하고 있는 히스톤의 메틸화 유무에 따라서 특정 세포의 분화 및 활성이 조절 될 수 있 다. 본 종설은 이러한 폴리콤 그룹 단백질들의 활성이 $\mathrm{T}$ 림프구 분 화와 활성에 미치는 영향에 대해 알아보았다. 


\section{본 론}

\section{1. 폴리콤 단백질들의 종류, 발현, 기능}

Polycomb Group $(\mathrm{PcG})$ 단백질은 초파리의 돌연변이 실험을 통 하여, 초파리 초기 발달과정에 중요한 역할을 하는 Hox 유전자 전 사를 억제하는 것으로 처음 알려졌다[4]. 이러한 기능은 초파리에 서 발견된 Trithorax Group (TrxG) 단백질들이 특정 유전자 전사 를 증진시키는 것과는 반대되는 작용을 하는 것으로 알려져 있다 [5]. PcG 단백질들의 기능이 억제된 돌연변이에서 척추의 기형성이 나타남을 미루어 보아, 척추동물에서도 PcG 단백질들의 기능은 잘 보존 되어 있음이 입증되었다[6]. PcG 단백질에 의한 유전자 전사 억제는 특정 유전자와 결합하고 있는 히스톤(histone)의 구조를 변 화시킴에 의한다고 알려져 있으며, 이러한 PcG 단백질들에 의한 히 스톤의 구조 변화에 사용되는 방법은 크게 메틸기(methylation)와 유비퀴틴(ubiquitin)을 특정 히스톤에 붙이는 방법에 의한다[7,8]. $\mathrm{PcG}$ 단백질들에 따라서 PcG 단백질들은 methyltransferase의 역 할과 ubiquitin ligase의 역할을 하는 효소 복합체라고 할 수 있다. 또한 몇몇 PcG 단백질들은 히스톤의 deacetylation을 유도하거나 DNA methylation을 유도하기도 한다[9,10]. 따라서 PcG 단백질들 의 활성에 따라 특정 유전자의 전사가 억제되며, 이러한 기능에 의 해 특정 세포의 표현형 변화가 일어난다.

PcG 단백질들은 진핵생물에서 잘 보존된 두 가지의 복합체를 이 루며, polycomb repressive complex 1 (PRC1)과 polycomb repressive complex 2 (PRC2)로 나뉜다[11,12]. PRC1에서 복합체를 이루 는 단백질은 4종류이며, BMI-1, CBX2, RING1A/B, EDR1 (PHC1) 등이 있다[11,12]. PRC2에서 복합체를 이루는 단백질은 3종류이며, $\mathrm{EED}, \mathrm{SUZ12}$, EZH2 (ENX2) 등이 있다[11,12]. PcG 단백질들을 연 구할 때 가장 고려해야 할 점은 PRC1과 PRC2의 복합체를 이루는 $\mathrm{PcG}$ 단백질들의 기능적 다양성과 이에 따른 PRC1과 $\mathrm{PRC} 2$ 의 복합 체 기능의 다양성을 고려해야 할 것이다. 대부분의 PcG 단백질들 은 RING-finger domain 또는 Zinc-finger domain을 가지고 있어 $\mathrm{DNA}$ 에 결합할 수 있는 능력을 가지며, 또한 각 단백질끼리 상호 작 용할 수 있는 기능을 가진다[11,12]. 이러한 각 PcG 단백질들의 기 능은 어떠한 단백질들이 PRC1과 PRC2 단백질 복합체 조합을 이 루는가에 따라 특정 target DNA가 달라질 수 있으며, 이에 따른 세 포 표현형 변화도 달라질 것이다. 실제로 PcG 단백질들이 PRC1과 PRC2 단백질 복합체를 이룰 때, 특정 기능이나 상황에 따라, 단백 질 복합체의 기능에 꼭 필요한 몇몇 단백질을 제외하고는 PRC1과 PRC2 단백질 복합체의 구성단위를 이루는 단백질들의 조합은 바 뀔 수 있다. 또한 PRC1과 PRC2는 개별적으로 또는 같이 일하며 유 전자 전사를 억제하는 것으로 알려져 있다. 이러한 구조적 기능적 다양성에 따라, PcG 단백질들의 기능은 상황에 따라 바뀔 수 있으 며, 단순히 메틸화나 유비퀴틴화에 의한 크로마틴 구조 변화의 기
능에 국한 시켜서는 안 된다고 생각하며, 아직 다른 많은 기능이 있 을 것이라고 추측된다.

$\mathrm{PcG}$ 단백질들이 히스톤을 메틸화시켜 특정 유전자를 억제하는 기전은 잘 알려져 있다(Fig. 1A). 우선 PRC2 단백질 복합체가 target 유전자의 promoter region에 PRC1 단백질 복합체의 이동을 유 도하는 것이 알려져 있으며, PRC2 단백질 복합체의 한 subunit인 $\mathrm{EZH} 2$ 가 H3 히스톤의 lysine 27번에 세 개의 메틸기를 붙이는 것으 로 알려져 있다[13,14]. 즉 EZH2는 특정 히스톤에 세 개의 메틸기 (H2K27me3)를 붙이는 methyltransferase이다[11,12]. 특정 히스톤 에 세 개의 메틸기(H2K27me3)가 붙으면 특정 유전자의 전사는 억 제되며, 이러한 예는 특정 세포의 분화 시 후생학적 연구에 의해 이 미 많이 알려져 있다. PRC2 단백질 복합체가 target 유전자의 promoter region에 PRC1 단백질 복합체의 이동을 유도할 때 중요한 단백질은 chromobox (CBX) 단백질들이다[15]. CBX는 메틸기가 붙은 lysine에 결합하기 때문에 메틸화된 히스톤과 PRC1 단백질 복합체를 연결하는 매개 역할을 한다(Fig. 1A) [11,12,15]. PRC1 단
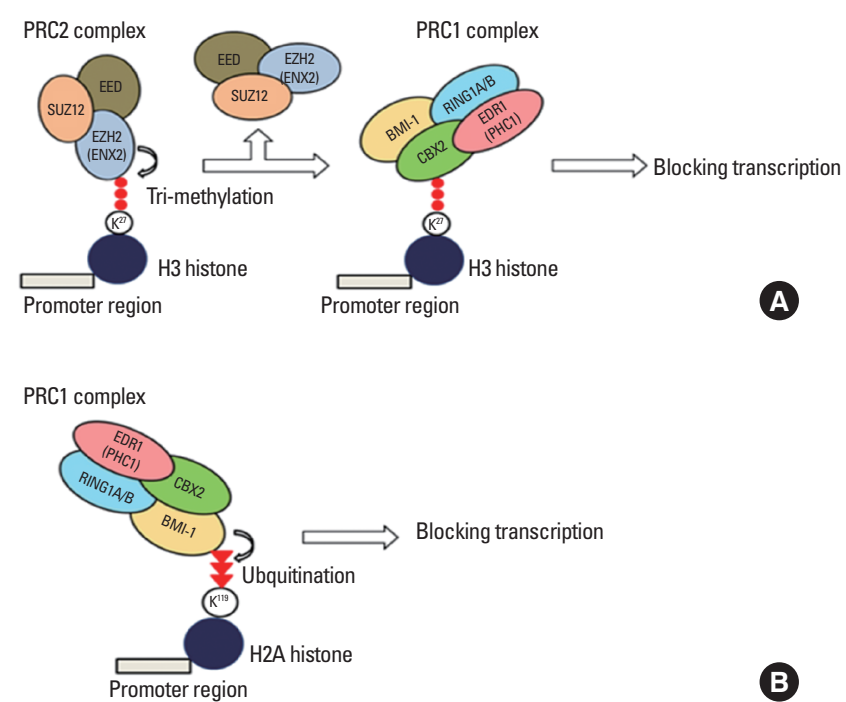

B

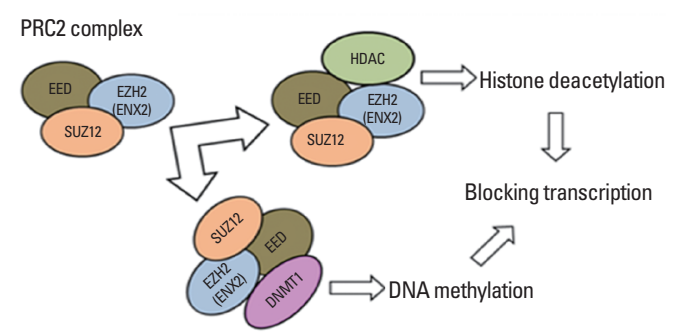

C

Fig. 1. Transcriptional inhibition by polycomb proteins [10-17]. (A) Trimethylation of $\mathrm{K} 27$ residue on $\mathrm{H} 3$ histone by polycomb proteins blocks the transcription of target gene, (B) Ubiquitination of K119 residue on $\mathrm{H} 2 \mathrm{~A}$ histone by polycomb proteins blocks the transcription of target gene, (C) Either histone deacetylation or DNA methylation by polycomb proteins blocks the transcription of target gene. 
백질 복합체의 경우 PRC1 단백질 복합체에 의한 trimethylation (H2K27me3)을 유지하거나, H2A 히스톤의 lysine 119번을 유비퀴 틴화(H2AK119ub) 하는 것으로 알려져 있다[12]. 이때 유비퀴틴 ligase 역할을 하는 것은 PRC1 단백질 복합체의 subunit 중 Ring 단 백질들과 BMI-1으로 알려져 있다(Fig. 1B) [16]. 이러한 특정 히스 톤의 유비퀴틴화(H2AK119ub)는 RNA polymerase II에 의한 전사 과정을 억제하여 결과적으로 특정 유전자의 전사를 억제한다[17].

PRC1 단백질 복합체 내의 몇몇 단백질은 히스톤의 deacetylation 을 유도하며, 또한 DNA methylation을 유도하기도 한다(Fig. 1C). 히스톤의 deacetylation을 유도할 때 중요한 단백질은 EZH2와 $\mathrm{EED}$ 복합체로 알려져 있으며, 히스톤의 deacetylation 역시 특정 유전자의 전사를 억제한다고 알려져 있다. 이때 $\mathrm{EZH} 2$ 와 EED 복합 체는 histone deacetylase (HDAC)와 결합한다도 알려져 있다(Fig. 1C) [9]. DNA methylation의 경우 PRC1 단백질 복합체가 직접적 으로 DNA methylation을 유도하는 것이 아니라 히스톤의 deacetylation을 유도할 때 중요한 단백질인 EZH2와 EED 복합체에 DNA methyltransferase I (DNMT1)을 결합하여 일어난다고 보고 되었다(Fig. 1C) [10]. 또한 이러한 DNMT1과 PRC1 단백질 복합체 의 결합은 PRC1 단백질 복합체의 히스톤 deacetylation 활성에 중 요하다고 알려져 있다[10].

$\mathrm{PcG}$ 단백질들에 의한 생체 내 조절은 줄기세포 분화부터 암세포 생성까지 다양한 생명현상에서 연구되고 있지만[11], 면역세포, 특 히 T 림프구의 분화 및 활성 조절에 대해서는 몇몇 $\mathrm{PcG}$ 단백질들을 제외하고는 잘 알려져 있지 않았다. $\mathrm{PcG}$ 단백질 중에 지금까지 면 역세포 활성에 영향을 주는 물질은 크게 3가지 PcG 단백질(BMI-1, MEL-18, EZH2)로 알려져 있으며, 이러한 단백질들의 발현 및 기능 이 $\mathrm{T}$ 림프구의 분화 및 활성 조절에 미치는 영향은 다음과 같다.

\section{2. $\mathrm{BMI}-1$ 이 T 림프구의 분화 및 활성 조절에 미치는 영향}

골수 내 림프구 발달 과정에서 림프구 분화 과정과 BMI- 1 의 발 현 양상은 정반대의 양상을 보인다[18,19]. 즉, $\mathrm{CD} 34^{+}$조혈모세포에 서는 BMI-1의 발현 양상이 높게 나타나며, 일단 특정 면역 세포로 분화된 CD34 세포에서는 BMI-1의 발현이 감소하는 것으로 알려 져 있다[19]. 이러한 결과는 BMI-1이 초기 림프구 분화 과정에 중요 한 역할을 한다는 것을 암시한다. 이러한 생각을 뒷받침하는 예로 $B m i 1$ 유전자를 과발현한 생쥐는 림프구의 발달이 과도하게 일어 나며, 결과적으로 B cell lymphoma가 자연적으로 생긴다[20]. 반면 $B m i 1$ 유전자가 결핍된 생쥐에서는 림프구 발달이 정상 생쥐보다 덜 일어나게 된다[21]. 실제로 BMI-1의 기능은 조혈모세포의 selfrenewal을 유지하는데 중요하다고 알려져 있다[21,22]. 이때 BMI-1 은 $\mathrm{p} 16^{\mathrm{Inkaa}}$ 와 $\mathrm{p} 19^{\mathrm{Arf}}$ 의 전사를 억제시켜 $\mathrm{p} 53$ 의존적 세포 사멸이나 세포 노화, 세포 분열을 억제하는 기능을 한다[21,22].

흥선 내에서 발달하는 $\mathrm{T}$ 림프구의 발달 과정을 특정 $\mathrm{PcG}$ 단백질
의 양상에 따라 분류해 보면, $\mathrm{BMI}-1^{+} / \mathrm{EZH} 2^{-}, \mathrm{BMI}-1^{+} / \mathrm{EZH}^{+}, \mathrm{BMI}-1^{-} /$ $\mathrm{EZH} 2^{+}$이들 세 가지 형태의 세포로 나뉘며, $\mathrm{BMI}-1^{+} / \mathrm{EZH} 2^{-}$형태를 나타내는 $\mathrm{T}$ 림프구 전구체는 주로 흥선 내 $\mathrm{T}$ 림프구 발달 초기 세 포인 $\mathrm{CD} 4 \mathrm{CD} 8$ 상태의 전구체이며, $\mathrm{BMI}-1^{+} / \mathrm{EZH} 2^{+}$형태를 나타내 는 T림프구 전구체는 BMI-1 $1^{+} / \mathrm{EZH} 2^{-}$형태를 나타내는 $\mathrm{CD} 4^{-} \mathrm{CD} 8^{-}$ 상태의 전구체 이후에 발생한다. 또한, $\mathrm{BMI}-1^{-} / \mathrm{EZH} 2^{+}$형태를 나타 내는 $\mathrm{T}$ 림프구 전구체는 $\mathrm{CD} 4^{+} \mathrm{CD} 8^{+}$상태의 $\mathrm{T}$ 림프구이다[23]. 따라 서, $\mathrm{BMI}-1$ 의 기능은 $\mathrm{T}$ 림프구 발달 초기 세포인 $\mathrm{CD} 4^{-} \mathrm{CD} 8^{-}$상태의 전구체 발달에 중요한 역할을 하는 것으로 알려져 있다. 특히 $\mathrm{CD} 4^{-}$ $\mathrm{CD} 8^{-}$상태의 $\mathrm{T}$ 림프구 전구체가 $\mathrm{CD} 4^{+} \mathrm{CD} 8^{+}$상태의 $\mathrm{T}$ 림프구 전구 체로 발달 될 때, $\mathrm{BMI}-1$ 이 직접적으로 $\mathrm{p} 16^{\mathrm{Inkaa}}$ 와 $\mathrm{p} 19^{\mathrm{Arf}}$ 의 전사를 억 제하여 세포 분열을촉진시킨다는 것이 알려져 있다[24].

$\mathrm{BMI}-1$ 의 활성은 초기 $\mathrm{T}$ 림프구 분화 과정 이후 특정 $\mathrm{T}$ 림프구의 활성 조절에도 영향을 미친다는 보고가 나타나 있다. 우선 BMI-1 이 $\mathrm{Th}_{2}$ cell 발달을 촉진시킨다는 것이 알려져 있으며, memory $\mathrm{T}$ 림 프구 발달에도 중요한 역할을 한다는 것이 알려져 있다[25,26]. 이 러한 결과는 주로 Bmi-1 유전자가 결핍된 생쥐의 표현형을 관찰하 여 알려진 결과들이다[25,26]. GATA-3의 경우 BMI-1과 상호 작용 을 한다는 것이 면역침전법(immunoprecipiation)과 yeast-two hybrid $(\mathrm{Y} 2 \mathrm{H})$ analysis에 의해 입증되었다[25]. 이러한 상호 작용은 GATA-3의 유비퀴틴화를 억제하여, 결과적으로 GATA-3의 발현 을 안정화시켜 $\mathrm{Th}_{2}$ cell 발달을 촉진시킨다[25]. 또한, BMI-1은 memory T 림프구에서 발현하는 Noxa 유전자의 발현을 억제하여 memory T 림프구의 세포 사멸을 억제하는 것으로 알려져 있다 [26]. Noxa 유전자는 림프구를 비롯한 여러 세포에서 세포 사멸을 유도하는 유전자로 알려져 있으며[27], Noxa 유전자의 CpG island 에 위치하는 특정 히스톤에는 trimethylation (H2K27me3)이 일어 난다고 알려져 있다[26]. 그 밖에 BMI-1이 흥선 내 상피세포(thymic epithelial cell, TEC)의 세포 분열을 촉진시켜 생체 내에서의 흥 선 크기에 영향을 준다는 논문도 보고되었다[28].

\section{MEL-18이 T 림프구의 분화 및 활성 조절에 미치는 영향}

MEL-18의 활성은 흥선, 골수, 비장, 림프절, Peyer's patch 등 대부 분의 면역기관에서 활성을 보이는 것으로 알려져 있다[29]. Mel18 유전자가 결핍된 생쥐의 경우 대부분의 면역세포가 결핍을 보이는 현상을 나타내는데, 이러한 이유에 의해 MEL-18의 기능도 BMI-1 의 역할과 마찬가지로 초기 림프구 분화 과정에 중요한 역할을 할 것이라고 생각된다[29]. 하지만 MEL-18의 경우 BMI-1처럼 조혈모 세포의 self-renewal을 증진시키는 것이 아니라, 오히려 조혈모세포 의 self-renewal을 억제하는 것으로 나타났다[29]. 이러한 가설의 증 거는 Mel18 유전자가 결핍된 생쥐에서 Hoxb4 유전자의 전사가 증 가되며, 이에 따라 휴지기 상태 $\left(\mathrm{G}_{0}\right.$ stage)의 조혈모세포가 늘어나는 현상에 의한다. 따라서 조혈모세포에서 MEL-18의 기능은 오히려 
조혈모세포의 self-renewal을 억제하는 것이다[29].

따라서 림프구 분화에서 MEL-18의 기능은 조혈모세포의 selfrenewal을 유지하는 것보다는 조혈모세포에서 다른 면역세포로의 분화 과정에서 더욱 중요한 역할을 할 것이라고 생각된다. 특히 Mel18 유전자가 결핍된 생쥐의 경우, 골수 내 조혈모 세포는 IL-7에 대한 반응성이 현저하게 감소하는 것으로 나타났다[29]. 이러한 이 유에 의해서 MEL-18은 IL-7 수용체에 의한 STAT5 signaling [30] 에 중요한 역할을 하는 것으로 알려져 있다[29]. 또한 Mel18 유전자 를 과발현한 생쥐의 경우 특정 cyclin과 cyclin dependent kinase (CDK)의 활성이 억제됨에 따라, MEL-18이 세포 주기를 억제하는 기능을 가지고 있음을 밝혀 졌다[31]. 이러한 연구 결과는 B 림프구 수용체에 전달되는 항원에 의한 $\mathrm{B}$ 림프구의 세포 분열 정도를 측정 하였을 때, Mel18 유전자를 과발현한 생쥐 내에서 발달하는 B 림 프구의 세포 분열이 정상 생쥐 내에서 발달하는 B 림프구의 세포 분열 보다 억제 된다는 연구 결과에 의해 알려졌다[31].

MEL-18의 기능은 BMI- 1 의 기능처럼 초기 림프구 분화 과정 이 후 특정 $\mathrm{T}$ 림프구의 활성 조절에도 영향을 미친다는 보고가 나타 나 있다. 우선 BMI-1의 기능과 마찬가지로 MEL-18이 $\mathrm{Th}_{2}$ cell 발달 을 촉진시킨다는 것이 알려져 있다[32]. Mel18 유전자가 결핍된 생 쥐에서는 $\mathrm{Th}_{2}$ type cytokine들인 IL-4, IL-5, IL-13이 감소되며, 이러 한 결과는 IL-4 유전자의 메틸화와 GATA-3 발현 억제에 의한다 [32]. 하지만 MEL-18의 기능이 BMI-1의 기능처럼 memory T 림프 구의 발달에 중요한 역할을 하는지에 대한 연구는 아직 이루어져 있지 않다.

\section{4. $\mathrm{EZH} 2$ 가 T 림프구의 분화 및 활성 조절에 미치는 영향}

$\mathrm{EZH} 2$ 는 특정 히스톤에 세 개의 메틸기(H2K27me3)를 붙이는 methyltransferase이기 때문에 PcG 단백질 중 가장 중요한 기능을 하며, 또한 그만큼 많이 연구되고 있는 단백질이다. 또한 $\mathrm{EZH} 2$ 는 $\mathrm{EED}$ 와 함께 복합체를 이루어 히스톤의 deacetylation을 유도할 수 있으며, DNA methylation을 유발하는 DNMT1과 결합하기도 한 다[10]. EZH2의 기능은 면역세포보다는 줄기세포나 암 연구에서 더욱 많이 연구 되었으며, EZH2는 암세포에서 높은 발현 양상을 보이며, 암세포의 발달에서 tumor suppressor 역할을 하거나 oncogene 역할을 하는 양면성을 가진다[33,34]. Ezh2 유전자가 결핍된 생쥐의 경우, 개체로 발달하지 못하기 때문에 면역세포에서의 EZH2 의 기능 연구는 상대적으로 제한적이며, 그만큼 생체 내에서의 $\mathrm{EZH} 2$ 의 기능은 면역세포 기능 조절뿐만 아니라 다른 세포의 기능 에도 중요하다는 것을 암시한다[35]. 따라서 EZH2가 면역세포에 어떠한 영향을 미치는가에 대한 기능 연구에서 우선으로 고려되는 것은, $\mathrm{EZH} 2$ 유전자의 과발현 또는 결핍 시 일어나는 면역 세포의 표현형적 특이성이 아니라 EZH2의 표적이 되는 특정 유전자의 발 굴에 있다. 이러한 연구의 예로, $\mathrm{EZH2}$ 는 $\mathrm{Th}_{1}$ cell에서 IL-4와 IL-13
유전자의 CpG island에 위치하는 특정 히스톤에 세 개의 메틸기 (H2K27me3)를 붙인다고 알려져 있으며, $\mathrm{Th}_{2}$ cell에서는 이러한 trimethylation 양상이 안 보인다는 보고가 나와 있다[36]. 또한 세 포독성 $\mathrm{T}$ 림프구에서 발현하는 특정 killer immunoglobulin-like receptor (KIR) 유전자의 CpG island에 위치하는 히스톤에 세 개의 메틸기(H2K27me3)를 붙인다고 알려져 있다[37]. 또한, $\mathrm{EZH} 2$ 의 tyrosine residue를 $\mathrm{p} 56^{\mathrm{lck}}$ 가 인산화 시키면, $\mathrm{T}$ 림프구 내 $\mathrm{CD} 3$ 복합 체와 결합하는 zeta-associated protein-70 (ZAP-70)와 결합한다고 알려져 있다[38]. 하지만 이들 두 단백질의 결합에 의해 어떻게 $\mathrm{T}$ 림 프구 표현형이 바뀌는지는 알려져 있지 않다.

최근에는 $E z h 2$ 유전자가 결핍된 생쥐에 Ezh2 conditional knock in 생쥐를 만들어 EZH2가 면역세포로의 분화 과정에서 어떠한 역 할을 하고 있는가를 연구하고 있다. Ezh2 conditional knock in 생 쥐에서 얻어진 연구 결과에 따르면 EZH2는 조혈모 세포 내 BMI-1 의 기능과 유사하게, 조혈모세포의 세포 사멸을 억제하고, 세포 주 기를 $\mathrm{G}_{o}$ stage로 유지시켜 self-renewal을 유지하는데 중요한 것으 로 알려졌다[39]. 또한 EZH2는 조혈모세포가 특정 면역 세포로의 분화 시 myeloid origin인 면역세포의 분화를 유도하는 것으로 알 려졌다[40]. 앞서 기술한 바와 같이 $\mathrm{T}$ 림프구의 발달 과정을 특정 $\mathrm{PcG}$ 단백질의 양상에 따라 분류해 보면, $\mathrm{BMI}-1^{+} / \mathrm{EZH} 2^{-}, \mathrm{BMI}-1^{+} /$ $\mathrm{EZH} 2^{+}, \mathrm{BMI}-1^{-} / \mathrm{EZH} 2^{+}$이 들 세 가지 형태의 세포로 나뉜다[23]. $\mathrm{EZH2}$ 를 발현하는 $\mathrm{T}$ 림프구 전구체들은 주로 $\mathrm{CD} 4^{+} \mathrm{CD}^{+}$상태의 $\mathrm{T}$ 림프구 전구체이기 때문에 흥선 내 선택 과정(thymic selection) 이나 특정 lineage differentiation ( $\mathrm{CD} 4^{-} \mathrm{CD} 8^{+}$또는 $\mathrm{CD} 4^{+} \mathrm{CD} 8^{-}$thymocyte) 발달에 중요할 것이라고 추측된다. 하지만 이를 뒷받침하 는 증거는 아직 발표되어 있지 않다.

\section{5. 그 밖의 PcG 단백질들이 T 림프구의 분화 및 활성 조절에 미치는 영향}

그 밖의 PcG 단백질들 중 면역기관의 발달이나 면역세포의 분화 및 활성 조절에 중요한 역할을 하는 예는 CBX2, Ring1B, PHC1으 로 알려져 있다. CBX2, Ring1B, PHC1은 PRC1 단백질 복합체의 구 성단위들이다[11,12]. $C b x 2$ 유전자가 결핍된 생쥐의 경우 비장 내 vascular 또는 adrenal gland의 결핍 현상이 보이는데, 이러한 원인 은 adrenal 4 binding protein/steroidogenic factor-1 (Ad4BP/SF-1) 이라는 전사 인자의 발현이 감소되기 때문이라고 알려졌다[40]. Ring1B의 경우 BMI-1이나 MEL-18의 경우와 마찬가지로 $\mathrm{Th}_{2}$ cell 발달을 촉진시킨다고 알려졌으며 [41], 최근에는 Runx1/CBFb 전사 인자와 직접적으로 결합하여 BMI-1과 같이 면역세포의 초기 분화 에 중요한 영향을 미친다는 보고가 있다[42]. EDR1 (PHC1)의 경우 도 조혈모세포의 self-renewal에 중요한 역할을 한다는 보고가 있 다[43]. 


\section{결 론}

PcG 단백질들은 크로마틴의 구조를 여러 가지 형태로 변화시켜, 특정 유전자의 발현을 억제하는 전사억제자(transcription repressor)로 알려져 있다. PcG 단백질들이 특정 면역 세포의 발달이나 활 성에 중요한 작용을 한다는 것은 PRC1과 PRC2 단백질 복합체 내 의 각 각의 단위 단백질의 발현을 제거한 생쥐의 표현형을 보고 그 기능의 유추가 가능했다. 그 예로 PRC2 단백질 복합체 단위 단백질 인 BMI-1, MEL-18, Ring1B, PHC1 단백질의 활성이 제거된 생쥐에 서는 면역세포 분화에 문제점이 생기는데, 이러한 결과로 미루어 보아 BMI-1, MEL-18, Ring1B, PHC1 단백질들은 조혈모세포에서 면역 세포로의 분화에 중요한 역할을 하는 것으로 생각된다[22,29, 40,43]. 또한 PRC2 단백질 복합체 단위 단백질들은 대부분 $\mathrm{Th}_{2}$ cell 발달을 촉진시킨다고 알려졌다[25,26,32]. 하지만 이러한 연구는 대 부분의 연구가 특정 3 가지 PcG 단백질(BMI-1, MEL-18, EZH2)의 기능으로 국한되어 있으며, 다른 PcG 단백질들이 어떻게 면역세포 의 분화나 활성에 영향을 미치는가에 대한 연구가 더 필요할 것으로 생각된다. 또한 앞서 기술하였듯이 PcG 단백질들이 PRC1과 PRC2 단백질 복합체를 이룰 때, 특정 기능이나 상황에 따라, PRC1과 $\mathrm{PRC} 2$ 단백질 복합체의 구성 단위를 이루는 단백질들의 조합은 바 뀔 수 있다. 따라서 이러한 구조적 기능적 복잡성에 따라, 특정 면역 세포의 표현형은 달라질 수 있다. PcG 단백질들의 기능은 지금까지 생각했던 것보다 더욱더 복잡해 질 수 있고, 면역세포 내 PcG 단백 질들의 기능에 대한 연구는 아직 걸음마 단계라고 생각된다.

\section{REFERENCES}

1. Jaenisch R, Bird A. Eigenetic regulation of gene expression: how the genome integrates intrinsic and environmental signals. Nat Genet 2003;33: 245-54.

2. Morey L, Helin K. Polycomb group protein-mediated repression of transcription. Trends Biochem Sci 2010;35:323-32.

3. Schuettengruber B, Chourrout D, Vervoort M, Leblanc B, Cavalli G. Genome regulation by polycomb and trithorax proteins. Cell 2007;128:73545.

4. Moazed D, O'Farrell PH. Maintenance of the engrailed expression pattern by Polycomb group genes in Drosophila. Development 1992;116: 805-10.

5. Kennison JA. The polycomb and trithorax group proteins of Drosophila: trans-regulators of homeotic gene function. Annu Rev Genet 1995;29: 289-303.

6. Gould A. Functions of mammalian polycomb group and trithorax group related genes. Curr Opin Genet Dev 1997;7:488-94.

7. Cao R, Wang L, Wang H, Xia L, Erdjument-Bromage H, Tempst $\mathrm{P}$, et al. Role of histone $\mathrm{H} 3$ lysine 27 methylation in Polycomb-group silencing. Science 2002; 298:1039-43.

8. Wang H, Wang L, Erdjument-Bromage H, Vidal M, Tempst P, Jones RS, et al. Role of histone H2A ubiquitination in Polycomb silencing. Nature 2004;431:873-8
9. van der Vlag J, Otte AP. Transcriptional repression mediated by the human polycomb-group EED involved histone deaceylation. Nat Genet 1999;23:474-8.

10. Hernández-Muñoz I, Taghavi P, Kuijl C, Neefjes J, van Lohuizen M. Association of BMI-1 with polycomb bodies is dynamic and requires PRC2/ EZH2 and the maintenance DNA methyltransferase DNMT1. Mol Cell Biol 2005;25:11047-58.

11. Sparmann A, van Lohuizen M. Polycomb silencers control cell fate, development and cancer. Nat Rev Cancer 2006;6:846-56.

12. Nakayama T, Yamashita M. Critical role of the polycomb and trithorax complexes in the maintenance of CD4 T cell memory. Semin Immunol 2009;21:78-83.

13. Kuzmichev A, Nishioka K, Erdjument-Bromage H, Tempst P, Reinberg D. Histone methyltransferase activity associated with a human multiprotein complex containing the Enhancer of Zeste protein. Genes Dev 2002;16: 2893-905.

14. Cao R, Zhang Y. The functions of E(Z)/EZH2-mediated methylation of lysine 27 in histone H3. Curr Opin Genet Dev 2004;14:155-64.

15. Fischle W, Wang Y, Jacobs SA, Kim Y, Allis CD, Khorasanizadeh S. Molecular basis for the discrimination of repressive methyl-lysine marks in histone H3 by Polycomb and HP1 chromodomains. Genes Dev 2003;17: 1870-81.

16. de Napoles M, Mermoud JE, Wakao R, Tang YA, Endoh M, Appanah R, et al. Polycomb group proteins Ring1A/B link ubiquitylation of histone $\mathrm{H} 2 \mathrm{~A}$ to heritable gene silencing and X inactivation. Dev Cell 2004; 7:66376.

17. Shilatifard A. Chromatin modifications by methylation and uqiuitination: implications in the regulation of gene expression. Annu Rev Biochem 2006;75:243-69.

18. van der Lugt NM, Domen J, Linders K, van Roon M, Robanus-Maandag E, te Riele $\mathrm{H}$, et al. Posterior transformation, neurological abnormalities, and severe hematopoietic defects in mice with a targeted deletion of the bmi-1 proto-oncogene. Genes Dev. 1994;8:757-69.

19. Lessard J, Baban S, Sauvageau G. Stage-specific expression of polycomb group genes in human bone marrow cells. Blood 1998;91:1216-24.

20. Haupt Y, Bath ML, Harris AW, Adams JM. Bmi-1 transgene induces lymphomas and collaborates with myc in tumorigenesis. Bmi-1 transgene induces lymphomas and collaborates with myc in tumorigenesis. Oncogene. 1993;8:3161-4.

21. Park IK, Qian D, Kiel M, Becker MW, Pihalja M, Weissman IL, et al. Bmi1 is required for maintenance of adult self-renewing haematopoietic stem cells. Nature 2003;423:302-5.

22. Jacobs JJ, Kieboom K, Marino S, DePinho RA, van Lohuizen M. The oncogene and Polycomb-group gene bmi-1 regulates cell proliferation and senescence through the ink4a locus. Nature 1999;397:164-8.

23. Raaphorst FM, Otte AP, van Kemenade FJ, Blokzijl T, Fieret E, Hamer KM, Satijn DP, et al. Distinct BMI-1 and EZH2 expression patterns in thymocytes and mature T cells suggest a role for Polycomb genes in human T cell differentiation. J Immunol 2001;166:5925-34.

24. Miyazaki M, Miyazaki K, Itoi M, Katoh Y, Guo Y, Kanno R, et al. Thymocyte proliferation induced by pre- $\mathrm{T}$ cell receptor signaling is maintained through polycomb gene product Bmi-1-mediated Cdkn2a repression. Immunity 2008;28:231-45.

25. Hosokawa H, Kimura MY, Shinnakasu R, Suzuki A, Miki T, Koseki H, et al. Regulation of Th2 cell development by Polycomb group gene bmi-1 through the stabilization of GATA3. J Immunol 2006;177:7656-64.

26. Yamashita M, Kuwahara M, Suzuki A, Hirahara K, Shinnaksu R, Hosokawa $\mathrm{H}$, et al. Bmil regulates memory $\mathrm{CD} 4 \mathrm{~T}$ cell survival via repression of the Noxa gene. J Exp Med 2008;205:1109-20. 
27. Oda E, Ohki R, Murasawa H, Nemoto J, Shibue T, Yamashita T, et al. Noxa, a BH3-only member of the Bcl-2 family and candidate mediator of $\mathrm{p} 53$ induced apoptosis. Science 2000;288:1053-8.

28. Guo Y, Miyazaki M, Itoi M, Satoh R, Iwama A, Amagai T, et al. Polycomb group gene Bmil plays a role in the growth of thymic epithelial cells. Eur J Immunol 2011;41:1098-107.

29. Akasaka T, Tsuji K, Kawahira H, Kanno M, Harigaya K, Hu L, et al. The role of mel-18, a mammalian Polycomb group gene, during IL-7-dependent proliferation of lymphocyte precursors. Immunity. 1997;7:135-46.

30. Foxwell BM, Beadling C, Guschin D, Kerr I, Cantrell D. Interleukin-7 can induce the activation of Jak 1 , Jak 3 and STAT 5 proteins in murine T cells. Eur J Immunol 1995;25:3041-6.

31. Tetsu O, Ishihara H, Kanno R, Kamiyasu M, Inoue H, Tokuhisa T, Taniguchi M, Kanno M. mel-18 negatively regulates cell cycle progression upon B cell antigen receptor stimulation through a cascade leading to $\mathrm{c}$ myc/cdc25. Immunity 1998;9:439-48.

32. Kimura M, Koseki Y, Yamashita M, Watanabe N, Shimizu C, Katsumoto $\mathrm{T}$, et al. Regulation of Th2 cell differentiation by mel-18, a mammalian polycomb group gene. Immunity 2001;15:275-87.

33. Chou RH, Yu YL, Hung MC. The roles of EZH2 in cell lineage commitment. Am J Transl Res 2011;3:243-50.

34. Schlesinger Y, Straussman R, Keshet I, Farkash S, Hecht M, Zimmerman J, et al. Polycomb-mediated methylation on Lys27 of histone $\mathrm{H} 3$ pre-marks genes for de novo methylation in cancer. Nat Genet 2007;39:232-6.

35. O'Carroll D, Erhardt S, Pagani M, Barton SC, Surani MA, Jenuwein T. The polycomb-group gene Ezh2 is required for early mouse development. Mol Cell Biol 2001;21:4330-6.
36. Koyanagi M, Baguet A, Martens J, Margueron R, Jenuwein T, Bix M. EZH2 and histone 3 trimethyl lysine 27 associated with Il 4 and Ill3 gene silencing in Th1 cells. J Biol Chem 2005;280:31470-7.

37. Li G, Yu M, Weyand CM, Goronzy JJ. Epigenetic regulation of killer immunoglobulin-like receptor expression in T cells. Blood 2009;114:342230 .

38. Ogawa M, Hiraoka Y, Aiso S. The Polycomb-group protein ENX-2 interacts with ZAP-70. Immunol Lett 2003;86:57-61.

39. Herrera-Merchan A, Arranz L, Ligos JM, de Molina A, Dominguez O, Gonzalez S. Ectopic expression of the histone methyltransferase Ezh2 in haematopoietic stem cells causes myeloproliferative disease. Nat Commun 2012;3:623.

40. Katoh-Fukui Y, Owaki A, Toyama Y, Kusaka M, Shinohara Y, Maekawa $\mathrm{M}$, et al. Mouse Polycomb M33 is required for splenic vascular and adrenal gland formation through regulating Ad4BP/SF1 expression. Blood 2005;106:1612-20.

41. Suzuki A, Iwamura C, Shinoda K, Tumes DJ, Kimura MY, Hosokawa H, et al. Polycomb group gene product Ring1B regulates Th2-driven airway inflammation through the inhibition of Bim-mediated apoptosis of effector Th2 cells in the lung. J Immunol 2010;184:4510-20.

42. Yu M, Mazor T, Huang H, Huang HT, Kathrein KL, Woo AJ, et al. Direct recruitment of polycomb repressive complex 1 to chromatin by core binding transcription factors. Mol Cell 2012;45:330-43.

43. Ohta H, Sawada A, Kim JY, Tokimasa S, Nishiguchi S, Humphries RK, et al. Polycomb group gene rae28 is required for sustaining activity of hematopoietic stem cells. J Exp Med 2002;195:759-70. 